\title{
Gender Inequality In Orthopaedics Residency: Stigma Still Exist
}

\author{
Varun Gupta ${ }^{1}$, Sohael M Khan ${ }^{2}$, Pradeep K Singh ${ }^{3}$ \\ ${ }^{1}$ Fellow Arthroplasty, Dr H L Heeranandani Hospital, India \\ ${ }^{2}$ Assistant Professor \& Consultant Spine Division, Department of Orthopaedics, Jawaharlal Nehru Medical College, India \\ ${ }^{3}$ Chief Spine Surgeon, Department of Spine Surgery, Dr H L Heeranandani Hospital, India
}

Submission: March 19, 2017; Published: March 27, 2017

*Corresponding author: Sohael M Khan, Assistant Professor and Consultant Spine Division, Department of Orthopaedics, JNMC, Wardha, India

\section{Letter To Editor}

In today's modern era of $21^{\text {st }}$ century, It is hard to believe that most educated people in the society are still surrounded by social stigma and have that stereotypical thinking, when it comes to gender discrimination in orthopedics residency. According to the survey conducted by association of American medical colleges revealed that orthopedics has the lowest percentage of women residents as against other specialties. This fact is real and well documented.

Various hypothesis exist to address this issue, some believe that increased number of female medical students and graduates has led to a paradoxical shortage of orthopedics surgery residents. In other words, very small proportion of female graduates chooses to become orthopedic surgeons. Reasons for not to opt for orthopedics program includes: long working hours, increased physical demands, male domination and male nature . These factors exposes female to negative side of orthopedics program and they are biased to choose other specialities. This shows how education can serve as a platform in motivating social and gender inequalities rather than correcting them.

Another study conducted by AAOS (American association of orthopedics surgery) [1] found that negative environment created around women graduates such as family instability due to long working hours if they pursue orthopedics as a career persuade them not to choose orthopaedic specialty .
To overcome this issue, several articles from past 10 years describing how to address the gender imbalance and have to a suggestion of improving the education system by attracting women to orthopaedics surgery earlier in the process as well as mentoring women throughout their education and providing them with role modeling for careers in orthopaedic surgery. These are all good ideas, but it is unclear how we are measuring the effort. Whatever we are currently doing is simply not working. The data speaks for itself. But if are able to narrow the gender gap in the field of orthopaedics then this will bring diversification among health providers in each specialty and enables to improve the delivery of care to individual patients [2].

Gender equality will only be reached if we are able to empower women - Michelle Bachelet

\section{References}

1. Association of American Medical Colleges. 2012 Physician Specialty Data Book. Available at: https://members.aamc.org/eweb/ upload/2012\%20 Physician\%20Specialty\%20Data\%20Book.pdf Accessed March 18, 2013.

2. Mason BS, Parker S, Phillips D, Vetter CS, Templeton KJ, O'Connor MI, Sabesan VI, Shields NN. Stepping to the front: women in orthopaedic leadership. Available at: http://www.aaos.org/news/aaosnow/ mar13/clinical1.asp. Accessed March 18, 2013. 
This work is licensed under Creative Commons Attribution 4.0 License DOI: $10.19080 /$ OROAJ.2017.05.555667
Your next submission with Juniper Publishers will reach you the below assets

- Quality Editorial service

- Swift Peer Review

- Reprints availability

- E-prints Service

- Manuscript Podcast for convenient understanding

- Global attainment for your research

- Manuscript accessibility in different formats

( Pdf, E-pub, Full Text, Audio)

- Unceasing customer service

Track the below URL for one-step submission https://juniperpublishers.com/online-submission.php 